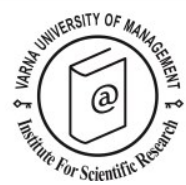

\title{
Combining Tourism Economic Account and Tourism Employment Module for a best measurement of tourism at a sub-national level
}

\author{
Philippe Jean-Pierre ${ }^{1}$ and David Perrain ${ }^{1 *}$
}

Received: 09/02/2015 Accepted: 31/07/2015

\footnotetext{
${ }^{1}$ Economics and Management Center of Indian Ocean, University of Reunion Island, France

Corresponding author: e-mail: perrain_david@yahoo.fr; phone: +336 92 878802; fax: +332 62214132
}

\begin{abstract}
For more than 15 years, the World tourism organization and other major multilateral organizations have worked on the development of reliable tools for assessing tourism related to others economic activities in a country: the tourism satellite account. Its implementation at a sub-national level is a challenging endeavour and requires going beyond this framework. A regional tourism economic account is a good answer to the demand for regional tourism economic data and to highlight the problematic of employment with a tourism employment module. This combination sheds a new light on the role of tourism in creating, preserving and diversifying jobs in the economy. We developed a regional tourism economic account (RTEA), based on the supply-side, in order to take advantage of the existence a system of regional accounts and to respond to the lack of domestic tourism data. All these developments have been applied in a French overseas region, Reunion Island. The results show their feasibility. The others ultra-peripheral regions of European Union, others European islands and more generally small island tourism economies can benefit from this experience, (i.e. all regions in which a system of regional account has been implented).
\end{abstract}

(C) 2016 Varna University of Management. All rights reserved

Keywords: Tourism economic contribution, tourism satellite account, tourism economic account, sub-national, tourism employment module

Citation: Jean-Pierre, P., D. Perrain (2016) Combining Tourism Economic Account and Tourism Employment Module for a best measurement of tourism at a sub-national level. European Journal of Tourism Research 12, pp. 99-113

\section{Introduction}

For more than 15 years, the World Tourism Organization and other major multilateral organizations have worked on the development of reliable tools for assessing tourism related to economic activities in relation with other industries in a country. The United Nations World Trade Organization (UNWTO) developed successive sets of international recommenddations on tourism statistics which eventually led to the birth of the tourism satellite account (TSA). TSA is the main statistical framework for the economic measurement of tourism. It has created relationships between tourism and other economic activities within the national accounts framework. It also allows extracting 
all tourism-related economic activities which are included in the national accounts but not identified as tourism, per se. Its implementation serves to improve the knowledge of tourism's relationship to overall economic activities, to provide an auxiliary instrument for designing more efficient policies and to create awareness among the various players not directly involved with tourism (Department of statistics \& economic measurement of tourism, 2001a, 2001b, 2002, 2003, 2004; TSA:RMF 2000, 2008; Jones, Munday and Roberts 2003; OECD 2000; Dwyer, Forsyth and Dwyer, 2011).

A voluminous literature has been published on the development, the uses and the implementation of the national tourism satellite account (TSA) and conferences have been organized to promote it (Department of Statistics \& Economic Measurement of Tourism, 2001a, 2001b, 2002, 2003, 2004; Libreros, Massieu \& Meis, 2006). These efforts allowed the adoption of the methodological framework and supporting system of tourism statistics for the TSA in 2008 (TSA:RMF 2008). The result of their efforts is the TSA's popularity. Thus, more than 70 countries have developed TSAs and on all continents (Libreros et al., 2006). In addition, a number of researchers have addressed the uses of the TSA in tourism analysis (Frechtling, 2009, $2010,2011)$. Others have complemented and extended TSAs by the use of economic models such as Computable General Equilibrium model (Blake, Durbarry, Sinclair \& Sugiyarto, 2001; Dwyer, Deery, Jago, Spurr \& Fredline, 2007; Meis \& Wilton, 1998; Dent, Clark \& Watts, 2004; Woollett, Townsend, Watts G, 2001), input-output model (Frechtling and Horvath, 1999; Van de Steeg \& Steenge, 2008; Tian, Mak \& Leung, 2011) or other econometric models (Ahlert, 2004). Eventually, researchers such as Frechtling (2010) and Hara (2008) have also written some primers or overviews on TSAs.

Nowadays, in a lot of worldwide tourist destinations, states are not the only administrative level which is interested in tourism economic information. The decentralization of political power and management of public resources involve developing a better understanding of the tourism economic contribution for regional policy makers and specialists in tourism development. Thus, knowledge of the economic contribution, going from the state to each of its tourism regions, has become an imperative policy. As a matter of fact, the pressure placed on regional tourism structures is increasingly substantial (Barber-Dueck and Kotsovos, 1996; Jones, 2009). Except for regional policy makers, specialists in local tourism development need to have comprehensive information at their disposal. Both of them need a coherent statistical framework with national accounts and the system of tourism statistics.

The satellite accounting approach is a suitable tool to assess the economic contribution of tourism to the national level but also to levels below (Brændvang, Dybedal, Johansen \& Sørensen, 2001; Cañada and Roig, 2004; Jones, Munday and Roberts 2005, 2009; McNicoll, 2003; Zhang and Billing, 2009). Nevertheless, the national TSA cannot help to determine the importance of tourism in different sub-regions, due to the unequal geographical distribution of tourism activity. In fact, this involves a regional development of the system of tourism statistics and a sub-national TSA (TSA:RMF 2008; Frechtling, 2008). Countries and regions, in which TSAs have been implemented, are able to gain a much clearer picture of tourism's position within their economy and to evaluate more accurately the benefits it offers. Even so, the transition between the national TSA and the regional TSA (RTSA) is not automatic and the regional implementation usually requires some adaptations (TSA:RMF 2008; Jones 2003). Sometime, regional statistics are often not appropriate, especially in small island tourist economies such as ultra-peripheral regions of European Union. Furthermore, employment and human resources are often insufficiently studied and the measure proposed by TSA:RMF (Table 7) is too generalized (Heerschap, 1999; ILO/UNWTO, 2008; Chernyshev, 2009). Thus, it doesn't answer to the needs of tourism authorities.

Whereas all these issues are at the core of all regional tourism strategy, the scarcity of data at 
the regional level and the relative neglect of this topic in the research literature involve going further to provide differential options or parallel solutions. C. Jones (2009), and T. Pham, L. Dwyer and R. Spurr (2008) suggests moving away from the "satellite" concept and building a regional tourism economic account (RTEA). This benefits from the wealth of conceptual debate around TSA and takes into consideration the regional tourism statistic system and the institutional employment requirements, especially coming from OECD. Indeed, labor should not be viewed simply as a factor in the production process but as human capital. People are part of tourism (Baum, 1995). Thus, it is important to develop, through a module inside the RTEA, a set of detailed employment tables in order to provide relevant statistics indicators for policy makers. Thus, RTEA creates another option for fully reconciling tourism economic demand and tourism supply as well as a new answer to the demand for good quality for tourism economic data.

The purpose of the article is to develop a RTEA, based on the supply-side, for taking advantage of the presence a system of regional accounts and to respond to the lack of domestic tourism data. The section I studies the technical principles of RTSA highlighted by the different regional implementations, as well as the guidelines of international manuals and the experts' suggestions. This also discusses the difficulties to implement it and the requirement to go beyond RTSA and to reach to a more flexible tool, such as regional tourism economic account. The section II analyzes alternative approaches and proposes to develop a RTEA, based on the supply-side, in order to take advantage of the presence of a system of regional accounts and to respond to the lack of domestic tourism data. The section III extends the RTEA with a tourism employment module. The last section presents the results of this implementation in Reunion Island, a French overseas region, which provides all the required characteristics. This implementation can provide a methodological framework for the others ultra-peripheral regions of European Union (Guadeloupe, French Guiana, Saint-Martin, Martinique, Azores, Madeira and Canary Islands) and others European islands and more generally small island tourism economies.

\section{The importance of tourism economic measurement at a sub-national level: from RTSA to RTEA}

Extension TSA to a sub-national level

Tourism generates additional demand at different territorial levels that needs to be measured using reliable and suitable tourism statistics. The extension of TSA can provide a useful instrument to respond to these requirements and for the planning of tourism policy at a regional level. To achieve this, a regional TSA (RTSA) has to follow the main technical principles of a TSA at the national level such as most of the concepts and definitions, as well as the classification of tourism characteristic products (Fletching, 2008; Zhang and Billing, 2009). Indeed, a RTSA benefits from the wealth of conceptual debate that has occurred at a national scale and has given the TSA a strong robustness (Jones et al., 2009).

An implementation needs developing RTSA technical approaches. The methodological framework and the experts highlight two possible categories: a regional approach and an interregional approach. The first approach relies on the regionalization of national data. This "top-down" method requires the existence of a National TSA and its availability in each region to allocate the national output of the tourism industry and the tourism consumption. Thus, this brings the benefits consistency between regions and the national TSA (Jones, 2003, 2005). Nevertheless, this method does not produce proper TSAs at the regional level. It only produces a very limited set of TSA indicators which do not accurately reflect the "peculiarities of the economic activity of each region" (working group for the Andalusia TSA, 2004). The second approach requires developing a fully specified TSA for any given region via regional statistic information, following the TSA coverage characteristics and definitions. This "bottom-up" method enables to produce estimates reflecting the nature of regional tourism supply and demand (Fletching, 2008). However, only a few regions (Andalucía in Spain, Wales and Scotland in the UK) have developed fully specified "bottom-up" TSAs 

at a sub-national level.

(Jones et al., 2009; Massieu, 2009) because they are data-hungry and time consuming. In practice, each implementation has to determine the best method according to its merits and problems. Several create a hybrid approach, i.e. they combine some principles of the "topdown" and "bottom-up" approaches. Thus, RTSAs are based on the national statistics ("top-down" method) and the combination of the visitor survey data and regional indicators ("bottom-up" method). Most of them use a set of regional indicators to allocate the national output of the tourism industry to each region and the tourism consumption of survey data.

The manuals for tourism satellite accounts do not give much guidance for regional breakdowns of the accounts (Brændvang, Dybedal, Johansen \& Sørensen, 2001). Discussions on this subject have continued in UNWTO and have sometimes served as a basis of reflexion for some authors. For instance, D.C. Fletching was influenced by the debates in UNWTO's conference in 2008 on "measuring tourism economic contribution at sub-national levels" to recommend some principles for RTSA implementation (Fletching, 2008 and 2009). Thus, extending the TSA brand at sub-national requires following the principles, coverage and methodologies of national TSA. This partly involves incorporating the ten tourism characteristic products and industries and other industries. $\mathrm{He}$ also suggests diminishing from ten to five specific values for assessing the economic contribution of visitors to a region, in order to reproduce at least the following four macroeconomic aggregates defined for the RMF:TSA (the internal tourism consumption, the gross value added of the tourism industries, and the tourism direct gross value added), estimates of employment in the tourism industries and a few quantitative indicators. At last, RTSA has to use predominantly account information, rather than estimates derived from models.

\section{From RTSA to RTEA}

In practice, "[...] RTSA implementation is a challenging endeavor" (Zhang and Billing, 2009). Indeed, a number of national accounting concepts are very difficult to apply to regions (TSA:RMF 2008; Jones 2003), especially without a guidance. Its development involves a lot of detailed technical constructions and estimates for the regional economic and tourism data (Jones, 2003; Zhang, 2001, 2002, 2005). Yet, regional statistics are often not appropriate, which makes it difficult to set up some quality RTSAs (Fletching, 2008). Furthermore, it could be difficult to get the appropriate resources as well as the involvement from central agencies (Jones et al., 2005). Fletching (2009) also points out that the lack of national TSA experience and/or the unavailable of quality regional data can limit the utilization of the TSA brand for countries and its regions.

Thus, alternatives approaches have been developed over the past few years. World Travel \& Tourism Council have established a system for producing estimates for the economic contribution of travel and tourism to 181 countries, 20 regions and the world overall. The estimates are derived from official national TSA statistics, where available, as well as other published data, and are complemented by economic modeling (WTTC/Oxford Economics, 2013). The WTTC provides information to find a solution to the lack of data, but these are not strictly TSAs. They estimate the direct economic contribution of travel \& tourism, being consistent with the UNWTO recommendations (WTTC/Oxford Economics, 2013). It does not provide the same robustness as the TSA, but it serves as a starting point for understanding the direct and indirect economic impact for those countries for which no relevant statistics are available.

Beyond this approach and other modelling ones, C. Jones (2009) suggests moving away from the "satellite" concept and building a regional tourism economic account. He focuses on supply difficulties in RTSA implementation and spots two main problems. On the one hand, input-output data could be not readily available. On the other hand, an assessment of TSA commodity outputs is not possible (Fletching, 2008; Jones, 2009). He, thus, develops what he calls a "next-best scenario", meaning a regional tourism economic account (RTEA), benefiting and adhering to the TSARMF. RTEA can create another option for fully reconciling tourism economic demand and tourism supply through different activities and a 
new answer to the regional demand for good quality for tourism economic data.

Difficulties can also come from the demand side. This implementation requires statistics data not only for inbound expenditures but also domestic tourism consumption. The lack of one of these two elements does not permit a direct internal tourism consumption estimate. In practice, it is a rare scenario. C.P. Cooper (2003) explains "[...] it is therefore desirable to analyze the two types of demand together, though in practice this is not as yet normally the case owing to the higher priority given to the collection of international tourism statistics and the greater difficulties of measuring domestic tourism". Thus, international tourism demand and its determinants have been the subjects of numerous studies over the past four decades (Crouch, 1994). This trend can be explained by the very existence of the balance of payments which requires inbound tourism data. A balance of payments is a statistical statement that summarizes the economic transactions of an economy with the rest of the world (IMF 2011). It takes into account income and financial transfers as well as goods and services, especially travel (travel is synonymous with the term tourism). Travel covers goods and services acquired from an economy by nonresident travelers. Thus, a country might be using its borders control to estimate the flow of inbound travelers, and a border survey to qualify these travelers as visitors and to measure their expenditures. Moreover, cities or regions also carry out these kinds of survey in order to measure and understand tourism activities on their territory and to estimate the impact of their promotion campaign on foreign client.

Domestic tourism is often left out from the observation whereas it is often more important than international tourism. D. G. Pearce (1995) and J. Latham (1998) estimate that the scale and volume of the domestic tourism worldwide exceeds that of international tourism. Christi Frent (2009) shows that for at least 14 Member states of the European Travel Commission (ETC), domestic tourism expenditures represent more than half of the internal (i.e. total) tourism ones. To overcome this, a few countries carry out specific surveys, but they are complex and costly. It is reasonable to think that only a very limited number of countries and even more regions - would be able to maintain continuous operations of this nature. Some other countries rely on their estimates on household budget surveys. Two drawbacks come to limit its potential. First, concepts and definitions do not always matched with those of the RMF:TSA. Secondly, households (or enterprises) surveys are generally not statistically representative at regional level because their samples are created at the national one.

Nevertheless, the strong demand of the regional deciders and professionals for quality tourism economic data encourages overcoming these difficulties. A solution would be to develop an alternative RTEA approach based on the supply side (i.e. production data of the regional account). Indeed, TSA:RMF implicitly recommends to follow a demand side approach (i.e. from estimate of internal tourism to tourism activities). The aim of this method is to benefit from an already existing system of regional accounts and administrative sources where, indeed, these ones exist in a region. Such a method implies to take into account data starting from production estimates of tourism characteristic activities and going to domestic tourism consumption. This is why this method was called a "supply-side approach". A system of regional accounts collects reliable information on the structure and developments of their economies. This provides input-output accounts, and notably the general supply and use tables (SUT). These tables describe the general economic balance of goods and services and the production accounts of the producers. Thus, they link the final demand to the industrial output levels, as well as hidden specific tourism transactions in accounts. This enables producing the full tourism commodity by industry for each characteristic products and industries whereas it is one of the main challenge in the RTSA or RTEA implementation. It means that regional account ensures the link with the tourism value added (in basic price) for each activity and the internal tourism consumption (in purchase price) for each product. 

at a sub-national level.

This approach enables to maintain the logical accounting and statistical consistency with the system of account. Indeed, founding this implementation on some visitor surveys produces some drawbacks, such as the compatibility with regional account data. For instance, the administration in charge of TSA compilation in France highlighted this issue regarding the hotel accommodation service. This internal tourism consumption should be equivalent to the total production since this activity is fully consumed by visitors. Yet, in 2005, these expenditures extracted from surveys amounted to 9 billion euros, although the French National Account recorded 15 billion Euros.

This method also relies on administrative sources because they provide complete, or almost complete, coverage of the regional population. Moreover, this allows keeping a coherent information with national accounts because they are usually based on them. Lastly, they are cheaper than other sources and often even free.

We have implemented this method in Reunion Island, a French overseas region in the Indian ocean. Despite being less known, Reunion Island provides all the necessary characteristics required: a strong demand of the regional tourism authority and an economic account. Unfortunately, domestic tourism expenditures datas are lacking. This implementation enables to elaborate it in a smaller region in terms of population (less than 1 million habitants) than the others implementations, such as Andalusia, Scotland and Wales. Van de Steeg (2009) has already implemented a TSA in a low-level population (Aruba), but he focused on measuring inbound tourism, and did not take account domestic tourism. Piraszewska (2006) also assessed the economic significance of tourism in islands of the Lesser Antilles, but using estimates of WTTC.

This implementation can provide a methodological framework for the others ultraperipheral regions of European Union (Guadeloupe, French Guiana, Saint-Martin, Martinique, Azores, Madeira and Canary Islands), and European islands (Sicilia,
Sardinia, ...) and more generally small island tourism economies. Indeed, The European system of national and regional accounts collects reliable information on the structure and developments of the economy of the Member States of the European Union and their respective regions.

\section{A RTEA based on supply side approach}

The implementation of RTEA based on supply side relies on a regional economic account, and notably the SUT. Producer's data can be extracted from the supply table of the SUT. Indeed, this offers the detailed level required to obtain tourism characteristic productions. The internal tourism consumption is directly derived from the data compiled in the uses table, taking into consideration the shares consumed by visitors. Indeed, in addition to connected or non specific activities, tourism characteristic activities are also consumed by non-visitors. Thus, a tourism share has to be estimated for each of them. Some activities are specifically designed for visitors. For instance, the production of accommodation services is only consumed by visitors. For these activities, the internal tourism consumption is equal to the final consumption in the SUT. Conversely, the production of food and beverage services or the retail trade are also consumed by nonvisitors. Thus, the share of visitors consumption has to be measured.

The second step of this method uses an administrative source. Tourism parts of these activities are estimated with an administrative declaration of the private employers (DADS): administrative information available at a national level as well as at a regional one. DADS is a declaratory formality which has to be filled by any enterprise with employees in France. It is a common document for the social security and the tax administration. This database contains information relating to the company and its employees. For each employee the following information are reported: the nature of the employment and qualification, starting date and end of pay period, the number of employed hours, the condition of employment (full time, part-time), the amount of compensation paid, etc. Its scope covers all the establishments with 
Jean-Pierre, P., D. Perrain (2016) / European Journal of Tourism Research 12, pp. 99-113

\begin{tabular}{|c|c|c|c|}
\hline $\begin{array}{l}\text { Living area } \\
\text { Activity }\end{array}$ & $\begin{array}{l}\text { Strongly equipped } \\
\text { communes }\end{array}$ & $\begin{array}{l}\text { Fairly equipped } \\
\text { communes }\end{array}$ & $\begin{array}{l}\text { Slightly equipped } \\
\text { communes }\end{array}$ \\
\hline $100 \%$ touristic activities & all the employment & all the employment & all the employment \\
\hline Strongly touristic activities & $\begin{array}{l}\text { Seasonal and part of } \\
\text { stable employment }\end{array}$ & $\begin{array}{l}\text { Seasonal and part of } \\
\text { stable employment }\end{array}$ & None employment \\
\hline Fairly touristic activities & $\begin{array}{l}\text { Seasonal and part of } \\
\text { stable employment }\end{array}$ & Seasonal employment & None employment \\
\hline Slightly touristic activities & Seasonal employment & None employment & None employment \\
\hline No touristic activities & None employment & None employment & None employment \\
\hline
\end{tabular}

Source : French National Statistics Institute

Figure 1. Decision rules in terms of tourism employment according the activity and the localization of the establishment

employees, except central administrations and state agents.

The French National Statistics Institute developed a methodology in order to estimate the part represented by employees related to tourism activities. Thus, each establishment could be described as "tourism" and the jobs related to it, then, recorded as "tourism", according to the tourism orientation and a typology of "communes" (French National Statistics Institute, 1997, 2002). A "commune" is the smallest administrative district of several European countries (NUTS 5). The typology of the "communes" relies on the level of tourism facilities, i.e. their tourism equipment: restaurant capacity, hotel capacity, camp sites capacity, second home density, places of interest, etc. The methodology also measures the impact of tourism in living areas where seasonality is low. In this case, this estimates the number of jobs related to the resident population and, by subtraction, the number of tourism jobs, according to the "employment per population" ratio in similar living areas. A typology of activities was built from a logistic model. Thus, a regression of the daily employment for each activity provided the tourism level in relation to activities reference (i.e. the activities of tourist lodging). This enabled a classification in 5 groups: $100 \%$ touristic, strongly touristic, fairly touristic, slightly touristic and non-touristic. Crosschecking of these criteria enables to define decision rules (cf. figure 1). For each commune/activity breakdown, the appropriate method was applied. Thus, if the industry was not $100 \%$ touristic, tourism shares of employment were used. The ratio was calculated with estimates of visitors (inbound and domestic) consumption reported into the SUT. Non-monetary indicators were also used.

Tourism ratio estimates a tourism part of value added for each activity. The sum of all these portions over all industries is the tourism direct gross value added (TDGVA). Thus: TDGVA $=\Sigma$ Tour $_{i} \times \vee A_{i}$, where Tour $_{i}$ is the tourism share for the activity ${ }_{i}$ and $V A_{i}$, the value added of the activity $i$. Adding to TDGVA, the taxes on production and imports less the subsidies on products and imports related to tourism products, allows obtaining the tourism direct Gross Domestic Product (TDGDP).

The combination between regional economic accounts and estimates based on an administrative source enable to reproducing the four macroeconomic aggregates defined for in the RMF:TSA: the internal tourism consumption, the gross value added of the tourism industries, and the tourism direct gross value added.

The repartition of the internal tourism consumption between its two components requires a third step and a third source: an inbound tourism survey. The results of this survey enable to estimate domestic tourism consumption, by subtracting inbound tourism 
expenditures from internal tourism expenditures. For Reunion Island, the regional agency of CSO and the regional tourism administration have conducted a survey of tourist flows from passengers departing from airports in the island, since 1989. Its objective has been to estimate the number of tourists and to know their motivations, their accommodation types and their expenditures in accommodation, foods and beverages, souvenirs, etc. Thus, 376 flights have been surveyed, 21,826 cards collected (on average) every year. Besides, physical indicators also provided information about the origin of visitors. Eventually, in the absence of quantitative data, professional advices could help by their knowledge of their activity.

\section{Highlighting tourism employment via a module}

A RTEA has to provide a better perception of tourism employment. However, its proposed measure in the TSA:RMF is not adequate, notably at a sub-national level. The table 7 of this framework has been too much generalized (Heerschap, 1999; ILO/UNWTO, 2008; Chernyshev, 2009) to respond to tourism authorities needs. The estimates of employment have to move beyond this picture and to describe the nature of employment, the quality of employees, etc. (Jones, 2009; Fletching, 2009). Indeed, labor should not be viewed simply as a factor in the production process but as human capital. People are part of tourism (Baum, 1995). This refers to the activities of people who take a trip and it is also a set of activities provided by people that cater mainly to visitors. Tourism requires not only quality in products and services, but also quality in human resources. These are the most valuable asset of the tourism sector (OECD, 2000; Chernyshev, 2009). Moreover, policy makers are particularly keen in measuring the contribution of tourism in terms of generating jobs in order to understand what is happening in the tourism related labor market and develop adequate employment policies and strategies. Specialists in tourism development also need to have at their disposal a comprehensive set of information. The lack of reliable statistics on quantitative and qualitative aspects of employment in the tourism industries causes a major problem in providing the policy makers with relevant statistics indicators to monitor and analyze developments in the tourism-related labor market.

It is important to develop a set of detailed employment tables to overcome this deficiency. This set has to integrate, through a module, different sources of micro-data on employment into the macro data of the RTEA. This combination between this module and the RTEA enables extending the scope of the tourism impact measurement.

A few countries tried to implement experimental employment module at a national level. Statistics Canada develops a human resource module for the tourism industry. This module is based on and rooted in the accounting framework of the Canadian tourism satellite account (CTSA). It provides statistics about jobs, hours worked and compensation. These statistics are available by gender, work status, age group, immigrant status and occupation. They use the same framework, concepts and definitions as the CTSA, but all these statistics are related to production in tourism industries aggregated on five industry groups (transportation, accommodation, food and beverage services, recreation and entertainment and travel service). Moreover, the tourism ratios which derived from the CTSA are applied in each group. Statistic Canada also applies this module to the regional level; Ontario was the first province to experiment it. The methodology is very similar to the one used for the HRM at the national level because the same data sources are available at both the national and provincial levels (Statistics Canada; 2010a, 2010b). Another experimentation was launched in a smaller province, Newfoundland and Labrador, with a smaller population (Statistics Canada; 2011). Tourism Research Australia has also provided a tourism employment atlas since 2004. Details by industry of employment, and by full-time and part-time employment status, are collected from the labor force survey. The tourism valueadded ratios from each industry are applied on all the tourism dependent activities. They derived the total of tourism employment from the regional scale, using information about the composition of local areas employment and using modeled domestic and international 
visitors regional expenditures data (Tourism Research Australia, 2011).

OECD has provided a manual on a module focused on tourism employment linked with the TSA. Different sources of micro-data on employment can be integrated, through the module, into the more aggregated macro data of the TSA (OECD, 2000). The tourism employment module presents a set of the most used key variables to describe the tourismrelated labor market, i.e. in terms of jobs, sociodemographic characteristics and other used information in the tourism industry, such as jobs on the side, nationality, seasonality, etc. Moreover, this guideline suggests to analyze employment with a supply-side perspective (i.e. from classification of enterprises and organizations that offer products and services to visitors). This also enhances the predominance of accounting information rather than estimates derived from models. However, the extension of an OECD tourism employment module to a sub-national level might appear difficult, owing to the number of practical and statistical issues that it raises. At the national scale, only a handful of countries produce meaningful statistics on employment in the tourism industries (Chernyshev, 2009). The extension to the sub-national level might be more difficult, owing to the number of practical and statistical issues that it raises. Yet, employment is a core of all regional tourism strategy.

Despite this complexity, this framework has still provided a main principle that any regional tourism employment module (RTEM) should follow: it has to be linked with the RTEA (i.e. to be coherent in terms of methodology, technical logic, concepts and definitions). This unity has reinforced their complementarily. Thone latter involves that the module does not only measure the employment in the tourism characteristic industries but also in all tourismdependent industries. OECD also suggests, founding, this statistical framework on a supplyside approach, because the demand-side perspective provides only crude estimates of the number of jobs or the total of the laborvolume of the employment generated by tourism (OECD, 2000). This ranking of estimates from the supply-side approach also enables to have a potential of reliable sources, especially at a regional level (Calafel, 2011; Mac Feely, Delaney, O'Donoghue, 2011; Zamboni, 2009).

This last step has to rely on employee's statistics from administrative sources, because they provide a complete enumeration of all the values in a population both at a national level and at the regional one. In Reunion Island, we chose employees data from the administrative declaration of the private employers (DADS). Its field has covered all the establishments with employees, except central administrations and state agents. In addition, the annual population census can cover the self-employed (i.e. employers, contributing family workers and own-account workers). These two sources have had discrepancies owing to their different nature, especially their field and so their estimates. Social data described held jobs, while the census investigated population (employees and the self-employed). Yet, some employed people also had a job on the side. Moreover, "[...] these second, or third jobs may either successively follow one another within the reference period or, as was the case when someone held an evening job as well as a daytime job, may run in parallel" (OECD, 2000).

RTEM is a set of input-output tables designed to describe the key facts of the standard demographic information, such as full/part time, gender, age and occupations. They also have taken into account annual average gross wages of employees and establishments by sizes. In each table, rows represent the tourism-related industries (i.e. the tourism characteristic activities, the tourism connected industries and the rest of the economic activities). According to the tables, columns contain information about the employees. For each of them, estimates include tourism ratios. Thus, table 1 focused on the estimates of the total population of tourism-related employment (employee and self-employed). Tables 2, 3, 4 and 5 contain information about tourismdependent employees by working scheme, employee by gender, by age and by occupation. Table 6 describes average gross wages of employees and table 7, the establishments by sizes. Lastly, table 8 represents data on self-employed coming from 
population, because of the discrepancy between the two sources.

\section{Results}

The first RTEA of Reunion Island was carried out on data from 2005 but its update for 2008 and 2010 is coming soon. Indeed, the refounding of regional accounts has impeded this update for two years. Besides, Reunion Island lived in important tourism crisis in 2006, because of sanitary crisis linking with chikungunya epidemic. This also complicated all possible revisions. Nevertheless, this old elaboration enables also to analyze the political repercussions of this research.

The internal tourism consumption was estimated at 846 million Euros in 2005. The transport (by road, water or air) was the first expenditure with $30 \%$ of the internal tourism consumption. This was the largest one because Reunion Island is far from its clients who mostly came from mainland France (two thirds derive from air transport). Visitors spent

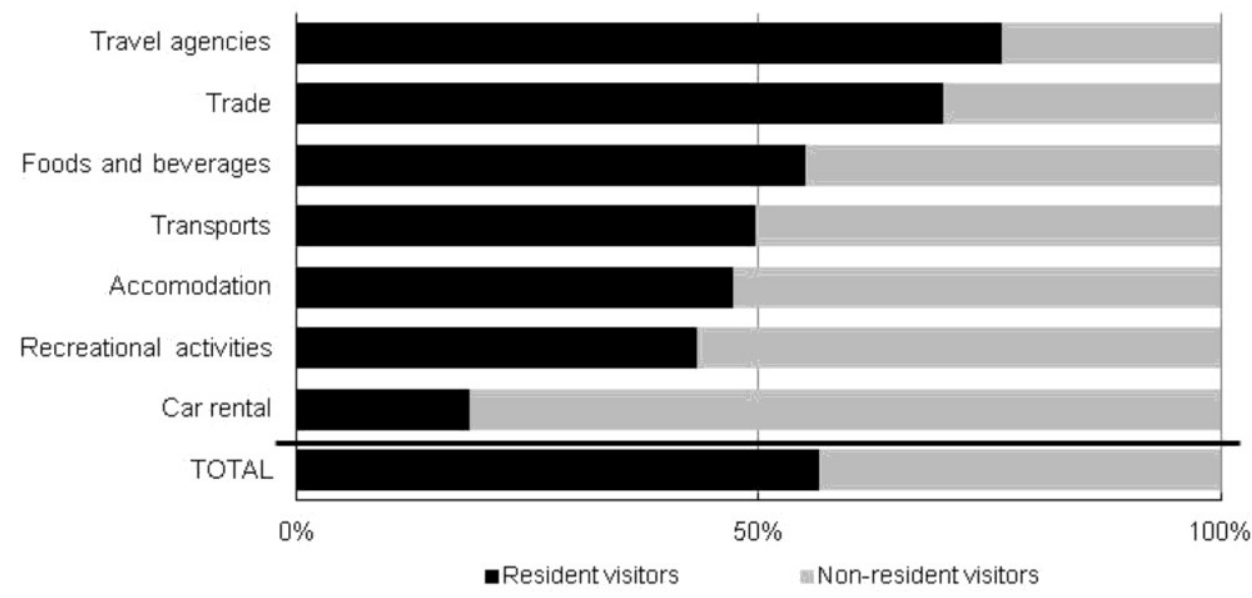

Source : CEROM 2009

Figure 2. Expenditure repartition by residence visitors in Reunion Island in 2005

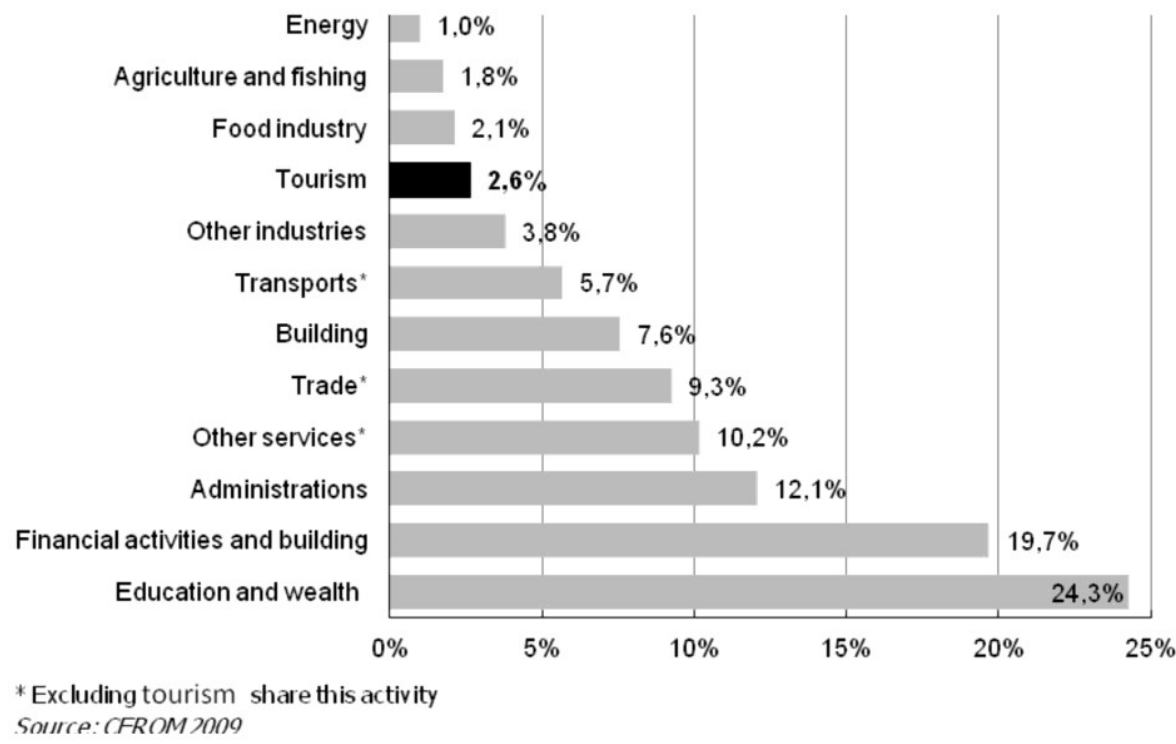

Figure 3. Value added repartition by activity in Reunion Island in 2005 
242 million Euros in retailers, street markets or directly from producers to purchase goods, in particular gifts, souvenirs and fuel. These represented the second source of expenditures and it was ahead of the emblematic tourist activities: "hotel and restaurant" (one quarter of the total). The domestic tourism consumption was estimated at 480 million Euros. With $57 \%$ of the internal tourism consumption in 2005 , it was higher than the inbound one.

This leadership of domestic tourism was a surprise for local authorities. This enabled to increase their perception of this sector. This involved a best taking into account of this kind of client in their strategy. Promotion campaigns were followed in direction to the domestic client after these results.

The direct value added generated by all the activities that provided goods and services to visitors was estimated at 290 million Euros. Thus, the tourism direct Gross Domestic Product (TDGDP) represented $2.6 \%$ of the Reunion GDP. Whereas this estimate seems to be low, the TDGDP exceeded the contribution of traditional sectors, such as agriculture and sugar industry. This enables for tourism policymakers to show the importance of tourism during the last planning strategy discussions. The accommodation activity was the largest contributor with more than one quarter of the TDGDP. The tourism contribution was lower than some destinations such as Mauritius where tourism represented $11.2 \%$ of the GDP. In fact, the tourism industry of the island was undersized compared to the "sister island". For example, in 2008, Reunion had less than one quarter of the hotel room capacity Mauritius had. Tourism was also the principal export earner. It generated $40 \%$ more revenue than the total exports of manufactured goods.

In 2005, the number of tourism employees was estimated at 9100 , according to the annual declaration of social data and 8600 according the population census. This small gap (less than $5 \%$ ) suggests that the number of jobs on the side was limited and tourism jobs were generally primary ones. A harmonization between them could be obtained in the next modules. Moreover, the number of self- employed was low: only 300 persons (i.e. $3 \%$ of the tourism employment and they concentrated especially in accommodation service). Thus, tourism created between 8900 and 9400 direct jobs in the island (i.e. $4 \%$ of the total employment). Converted in full-time equivalent, the number fell down to 6300 employees because $18 \%$ of employees had part-time jobs. Although the labor market in tourism had the reputation to be flexible, this part of part-times jobs was close to the rest of the economy (14\%).

Workers were predominantly younger than the active population: $60 \%$ of them were less than 35 years old, against $24 \%$ for all people. The female ratio was stronger than in the regional economy, but there were as many women as men. Employment generated by tourism is complex and heterogeneous because it goes from high quality professionals and managers to low skill jobs. Thus, most tourism employees are sales and services workers. Two thirds of employees occupied these kinds of jobs in tourism industries, against four on ten for the total. However, tourism offers opportunities for persons with high skills. Thus, $24 \%$ of tourism employees were managers, administrators or intermediate workers (against 27\% for the regional economy). Furthermore, the youth of tourism employees and the proportion of parttime workers led to an average annual wage $18 \%$ inferior to the total.

\section{Conclusion}

A best knowledge of the economic contribution of tourism at a sub-national level has become an imperative policy for local policymakers. The satellite accounting approach - TSA and its regional extension RTSA - are probably the most suitable tools to assess this economic measurement. However, their implementation is a challenging endeavour and requires going beyond this framework. RTEA creates another option for fully reconciling tourism economic demand and tourism supply. RTEA is also a new answer to the demand for good quality for tourism economic data. This would as well provide a best perception of tourism employment. Developing a RTEM enables to highlight this important problematic for tourism. The combination sheds a new light on the role of tourism. These data will allow policy-makers 
to target their measures in order to maximize the growth of tourism and its contribution to employment.

The unavailability of quality regional data can impede these implementations. We propose to develop a RTEA, based on the supply-side, in order to take advantage of the presence a system of regional accounts and to respond to the lack of domestic tourism data. Besides, this method could appear flawed, regarding the TSA:RMF. Nevertheless, even in the case of a lack of data about domestic tourism, our approach has provided results that could facilitate the decision making process. All these developments have been applied in a French overseas region, Reunion Island, and the results show their feasibility. The others ultraperipheral regions of European Union (Guadeloupe, French Guiana, Saint-Martin, Martinique, Azores, Madeira and Canary Islands) as well as other European islands and, more generally, small island tourism economies can benefit from this experience (i.e. all regions in which a system of regional account was implented). Lastly, this approach highlights the importance of the employment which is key in the policymakers reflexions.

This article calls for new researches. Indeed, it is important to evaluate the robustness of the tourism ratios when estimates of domestic tourism expenditures will be available. The different results should be confronted in order to investigate the different drawbacks of this method. Actually, this method provides results with an interval of 4 years, because of the necessity to work on final economic account. Regional authorities need more recent information. We have to find a solution to reduce this time-gap. At last, it is also important to develop an occupational approach (i.e. based on a distribution of the employed by occupation), because it would provide a different - but very useful - view of tourismrelated employment. This approach enables to group together people working in similar types of work, irrespective of the location the work is performed.

\section{References}

Ahlert, G. (2004). TSA for Germany: database of the satellite account and perspectives for integration into a sectoral disaggregated macroeconometric model. Paper presented at $7^{\text {th }}$ International Forum on Tourism Statistics. Stockholm, $9^{\text {th }}-11^{\text {th }}$ June 2004, Sweden

Barber-Dueck, C., D. Kotsovos (2003). The Provincial and Territorial Tourism Satellite Accounts for Canada. Ottawa: Ministry of Industry

Baum, T. (1995). Human Resource Management in the European Tourism and Hospitality Industry. London: Chapman and Hall

Blake A., R. Durbarry, G. Sugiyarto, M. T. Sinclair (2001). Modelling Tourism and Travel using Tourism Satellite Accounts and Tourism Policy and Forecasting Models. Discussion paper Series. Tourism and Travel Research Institute Nottingham. URL: http://www.nottingham.ac.uk/ttri (Accessed on 04.2001)

Braendvang A., P. Dybedal, S.Johansen, K. Sorensen (2001). Regional satellite accounts for tourism: Data, concepts, methods and applications. Paper presented at the $41^{\text {th }}$ Congress of the European Regional, $29^{\text {th }}$-September $2^{\text {nd }}$ 2001, Zagreb.

Calafel K. A. (2011). Measuring the economic contribution of tourism at local destination. The case of Navarra and Pamplona. Paper presented at the ${ }^{\text {nd }}{ }^{\text {Id }}$ International conference on the measurement and economic analysis of regional tourism, $27^{\text {th }}-29^{\text {th }}$ October 2011, Bilbao.

Cañada A., R. Roig (2004). Extensions of the Spanish TSA: regional estimates. Paper presented at $7^{\text {th }}$ International Forum on Tourism Statistics, $9^{\text {th }}-11^{\text {th }}$ June 2004 , Stockholm.

Chernyshev, I. (2009). ILO/UNWTO project on employment in the tourism industries: statistics component. Paper presented at $5^{\text {th }}$ UNWTO International conference on tourism statistics, $30^{\text {th }}$ March-2 ${ }^{\text {nd }}$ April 2009 Bali.

Cooper, C. P. (2003). Classic reviews in tourism. Bristol: Channel View Publications.

Crouch, G. (2004). The study of international tourism demand: a survey of practice. Journal of Travel Research, 32(4), 41-55. 
Dent, S., M. Clark, G. Watts (2004). Development of QGEMF-T A Dynamic Economy-Wide Model of Tourism. Brisbane: Economic and Statistical Research, Queensland Treasury.

Department of Statistics and Economic Measurement of Tourism (2001a). The Tourism Satellite Account as an ongoing process: Past, present and future developments. Madrid: World Tourism Organization.

Department of Statistics and Economic Measurement of Tourism (2001b). Enzo Paci papers on measuring the economic significance of tourism (Vol. 1). Madrid: World Tourism Organization.

Department of Statistics and Economic Measurement of Tourism (2002). Enzo Paci papers on measuring the economic significance of tourism (Vol. 2). Madrid: World Tourism Organization.

Department of Statistics and Economic Measurement of Tourism (2003). Enzo Paci papers on measuring the economic significance of tourism (Vol. 3). Madrid: World Tourism Organization.

Department of Statistics and Economic Measurement of Tourism (2004). Enzo Paci papers on measuring the economic significance of tourism (Vol. 4). Madrid: World Tourism Organization.

Department of Statistics and Economic Measurement of Tourism (2005). Adapting the National Tourism Satellite Account (TSA) project to sub-national levels. Madrid: World Tourism Organization.

Dwyer, L., M. Deery, L. Jago, R. Spurr, L. Fredline (2007). Adapting the Tourism Satellite Account conceptual framework to measure the economic importance of the meetings industry. Tourism Analysis, 12 (2), 247-255.

Dwyer, L., P. Forsyth, W. Dwyer (2011). The travel and tourism competitiveness index as a tool for economic development and poverty. In Moutinho L. (2011) Strategic management in tourism. Wallingford: $C A B$ International (33-52).

Frechtling, D. C., E. Horváth (1999). Estimating the multiplier Effects of tourism expenditures on a local economy through a regional Input-Output model. Journal of Travel Research, 37(4), 324-332.
Frechtling, D.C. (2008). Measurement and analysis of tourism economic contributions for sub-national regions through the Tourism Satellite Account. Paper presented at International Conference on Measuring Tourism Economic Contribution at sub-national levels, $29^{\text {th }}-31^{\text {th }}$ October 2008, Malaga

Frechtling, D. C. (2009). Clarifying and extending the TSA brand. Paper presented at $5^{\text {th }}$ UNWTO International conference on tourism statistics, $30^{\text {th }}$ March-2 ${ }^{\text {nd }}$ April 2009 Bali.

Frechtling, D. C. (2010). The tourism satellite account a primer. Annals of Tourism Research, 37(1), 136-153.

Frechtling, D. C. (2011). Confessions of a data junkie by Douglas. In L. Dwyer (2011), The Discovery of Tourism Economics. Bingley: Emerald Group Publishing Ltd, 57-72.

Frechtling, D. C., E. Horváth (1999). Estimating the Multiplier Effects of Tourism Expenditures on a Local Economy through a Regional Input-Output Model. Journal of Travel Research, 37(4), 324-332.

French National Statistics Institute (1997). Employee estimates, the "Montpellier" method. Discussion paper Series. French National Statistics Institute. URL: http://www.chiffres-tourisme-paca.fr (Accessed on 1997)

French National Statistics Institute (2002). Methodology of the employee estimates Discussion paper. French National Statistics Institute. URL: http://www.chiffres-tourisme-paca.fr (Accessed on 2002)

Frent, C. (2009). Some issues of the comparability of TSA aggregates among countries. In Department of Statistics and Economic Measurement of Tourism (2002) Enzo Paci papers on measuring the economic significance of tourism (Vol. 2). Madrid: World Tourism Organization. 263275.

Geddes, K., R. Grobler (2008). South Africa: tourism statistics and the tourism satellite account at a sub-national level. Paper presented at International Conference on Measuring Tourism Economic Contribution at sub-national levels, $29^{\text {th }}-31^{\text {th }}$ October 2008, Malaga 
Hara, T. (2008). Quantitative Tourism Industry Analysis - Introduction to I-O/SAM modeling and Tourism Satellite Accounts. Abingdon: Routledge

Heerschap N.MN. (1999). The employment module for the tourism satellite account of the OECD. Paper presented at Enzo Paci world conference on the measurement of the economic impact of tourism, $15^{\text {th }}-18^{\text {th }}$ June 1999, Nice.

International Labor Office and World Tourism Organization (2008). Sources and methods: Labor statistics. Employment in the tourism industries (Special edition). Madrid: World Tourism Organization

International monetary fund (2011). Sixth Edition of the IMF's Balance of Payments and International Investment Position Manual. New York: International monetary fund

Jones, C. (2005) Major Events, Networks and Regional Development. Regional Studies. 39 (2) $185-195$

Jones, C. (2009). Tourism's economic contribution at sub-national level. The regional TSA: complements and extensions. In Department of Statistics and Economic Measurement of Tourism (2002) Enzo Paci papers on measuring the economic significance of tourism (Vol. 6). Madrid: World Tourism Organization. 207-225.

Jones, C., M. Munday, A. Roberts (2003). Regional Tourism Satellite Accounts: A Useful Policy Tool? Urban Studies, 40(13) 2777-2794.

Jones, C., M. Munday, A. Roberts (2005). First steps tourism satellite account project: English regions. Cardiff: Welsh Economy Research Unit

Jones, C., M. Munday, A. Roberts (2009). Top down or bottom up? Issues in the development of subnational tourism satellite accounts. Current Issues in Tourism, 12(4), 301-313.

Libreros, M., A. Massieu, S. Meis (2006). Progress in Tourism Satellite Account implementation and development. Journal of Travel Research, 45(1), 83-91.

Massieu, A. (2009). Developing tourism statistics at the sub-national level: the measurement of flows of trips and visitors. In Department of Statistics and Economic
Measurement of Tourism (2009) Enzo Paci papers on measuring the economic significance of tourism (Vol. 6). Madrid: World Tourism Organization. 3-32.

Massieu, A. (2012). Measuring and Analyzing Regional Tourism: towards a set of general guidelines. Prior to Venice Seminar. Paper presented at first Seminar on Regional Tourism: setting the focus, $5^{\text {th }}-6^{\text {th }}$ June 2012, Venice

MacFeely, S., D. Jillian, F. O'Donoghue (2011). Using Business Registers to Conduct a Regional Analysis of Enterprise Demography and Employment in the Tourism Industries. Paper presented at the ${ }^{\text {II }}{ }^{\text {nd }}$ International conference on the measurement and economic analysis of regional tourism, $27^{\text {th }}-29^{\text {th }}$ October 2011, Bilbao.

McNicoll, L. (2003). Towards a Tourism Satellite Account for Scotland. Glasgow: University of Strathclyde.

Meis, S., and D. Wilton (1998). Assessing the economic outcomes of branding Canada: Applications, results and implications of The Canadian Tourism Satellite Account. Paper presented at the 29th annual conference of the Travel and Tourism Research Association, $15^{\text {th }}-17^{\text {th }}$ June 1998, Portland.

Latham, J. (1998). Patterns of international tourism. Progress in Tourism and Hospitality Research, 4(1), 45-52.

OECD (2000). Measuring the Role of Tourism in OECD Economies. The OECD Manual on Tourism Satellite Accounts and Employment. Paris: OECD.

Pearce, D. G. (1995). Planning for tourism in the 90s: an integrated, dynamic, multiscale approach. In R. Bulter and D.G. Pearce (1995) Change in tourism: people, places, processes. Abingdon: Routledge.

Pham, T. D., L. Dwyer, R. Spurr (2010). Regional Economic Contribution of Tourism Destinations in Queensland. Australia: STCRC

Piraszewska, K. (2006). Economic significance of tourism in the Lesser Antilles. Miscellanea Geographica, 12, 269-275

Statistics Canada (2010a). Human resource module of the tourism satellite account, 2010. Ottawa: Ministry of Industry. 
Statistics Canada (2010b). Human resource module of the tourism satellite account: a pilot study for Ontario. Ottawa: Ministry of Industry.

Statistics Canada (2011). Human resource module of the tourism satellite account: a pilot study for Newfoundland and Labrador 1997 to 2009. Ottawa: Ministry of Industry.

Steenge, A., A. Van de Steeg (2010). Tourism multipliers for a small Caribbean island state: the case of Aruba. Economic Systems Research, 22(4), 359-384.

Teigeros L. R. (2008). Creating Regional Tourism Satellite Accounts: the case of Andalusia. Paper presented at International Conference on Measuring Tourism Economic Contribution at subnational levels, $29^{\text {th }}-31^{\text {th }}$ October 2008, Malaga.

Tian E., J. Mak, P. Leung (2011). The Direct and Indirect Contributions of Tourism to Regional GDP: Hawaii. Hawaii: The economic research organization at the University of Hawaii.

Tourism Research Australia (2011). The Economic Importance of Tourism in Australia's Regions. Canberra: Australia government.

United Nations Statistics Division, Statistical Office of the European Communities, Organization for Economic Co-operation and Development and World Tourism Organization (2000). Tourism Satellite Account: Recommended methodological framework. Madrid: World Tourism Organization. (Here in referred to as "TSA:RMF 2000")

United Nations Statistics Division, Statistical Office of the European Communities, Organization for Economic Co-operation and Development and World Tourism Organization (2008). 2008 Tourism Satellite Account: Recommended methodological framework. Madrid: World Tourism Organization. (Here in referred to as "TSA:RMF 2008")

Van de Steeg, A. M. (2009). Accounting for Tourism, The Tourism Satellite Account in Perspective. The Hague: Statistics Netherlands.
Van de Steeg, A. M., M. Albert, E. Steenge (2008). Integrating the TSA and InputOutput Methodology in Tourism Impact. Paper presented in Proceedings the Intermediate Input-Output Meeting, $15^{\text {th }}$ 21th November 2008, Sevilla.

Woollett, G., J. Townsend, G. Watts (2001). Development of QGEM-T a computable general equilibrium model of tourism. Brisbane: Economic and Statistical Research, Queensland Treasury.

Working group for the development of a TSAAndalusia (2004). Quoted by, D. C. Frechtling 2008. Measurement and analysis of tourism economic contributions for sub-national regions through the Tourism Satellite Account. Paper presented at Proceedings of the Knowledge as Value Advantage of Tourist Destination, Malaga.

World Travel \& Tourism Council and Oxford Economics (2013). Methodology for producing the 2013 WTTC/Oxford Economics, travel \& tourism economic impact research. Report. World Travel \& Tourism Council and Oxford Economics. URL: http://www.wttc.org/ (Accessed on 16.12.2005).

Zamboni, R. (2009). Employment Information System in the tourism industries: the experience of Brazil. Paper presented at $5^{\text {th }}$ UNWTO International conference on tourism statistics, $30^{\text {th }}$ March-2 ${ }^{\text {nd }}$ April 2009 Bali.

Zhang, J. (2001). The impact of tourism on the economies of Danish Regions. Copenhagen, Denmark: Akf Forlaget.

Zhang, J. (2002). Tourism impact analysis for Danish regions. Tourism economics. 8 (2). 165-188.

Zhang, J. (2005). Documentation on Regional Tourism Satellite Accounts in Denmark. Copenhagen, Denmark: Akf Forlaget.

Zhang, J. and P. Biling (2009). Regionalized tourism satellite account for Denmark: methodology and results. In Department of Statistics and Economic Measurement of Tourism (2009) Enzo Paci papers on measuring the economic significance of tourism (Vol. 6). Madrid: World Tourism Organization (227-246). 